\title{
ジャワの人類化石含有層
}

\author{
市原実* 渡辺直 経**
}

\section{Hominid-Fossil Beds in Java}

\author{
Minoru Itihara* and Naotune Watanabe**
}

In and around the Kendeng Hills, Central and East Java, many sites of hominid-fossils have been found since the discovery of Pithecanthropus erectus by DuBois (Fig. 1, 2). Among these, the sites in Trinil, Modjokerto and Sangiran areas are very famous as representative ones.

1. The Pliocene-Pleistocene sediments in the afore-said areas are divided into Kalibeng Formation, Putjangan Formation, Kabuh Formation and Notopuro Formation in ascending order. However, the hominid-fossils have occurred only in Putjangan Formation (early Pleistocene) and Kabuh Formation (middle Pleistocene) (Fig. 3-5).

2. These hominid-fossils can be subdivided into the newer and smaller type (Pithecanthropus erectus) and the older and larger type. The former includes $P$. a and $P$. I-III, while the latter, which includes Homo modjokertensis, P. b, P. IV, P. dubius and Meganthropus palaeojavanicus, is similar to Homo habilis found from Africa.

3. K-Ar ages of Putjangan Formation and Kabu Formation show $1.9 \pm 0.4$ m.y. and 0.7 to $0.5 \mathrm{~m}$.y. respectively.

4. The Indonesian-Japanese cooperative project on hominid-fossil beds in Central and East Java was started in 1976 . The result of this project will be published by Geological Survey of Indonesia.

ジャワの人類化石含有層の予察ならびに同層について のインドネシア・日本の共同研究推進のために, 筆者ら は 1975 年 1 月に約 2 週間ジャワを訪れた. この間, ジョ クヤカルタのガジャ・マダ大学自然人類学教室の JACOB 教授の好意により，同教室の SOEPRIJO・SUYANT 両氏 の案内でサンギラン, サンブングマチャン, ソンデ, ト リニル, モジョケルトの人類化石産出地点を見学するこ とができた（図 1)。 ，また，バンドン地質調查所の関係 研究者, バンドン工科大学の SARTONO 教授を訪門する こともできた。

ここでは，人類化石の産出で有名なトリニル，サンギ ラン，モジョケルト地域の既存の層序学的研究を，おも に, Koenigswald (1940) にもとづいて紹介し, ジャワ の化石人類の問題点などについても説明したい.なお，
ジャワの人類化石と年の含有層の研究史やジャワの化石 人類の問題点については, 筆者の一人 ·渡辺 (1976) に よって詳しく紹介されているので，その論交を参照して いただきたい。

$$
\text { トリ ニル }
$$

オランダの DuBors は 1891〜1892 年に, ソロ川の川 岸で, Pithecanthropus erectus の大臼歯・頭蓋骨 (P. I) · 左大腿骨化石を発見した. DuBors (1896) による含人類 化石層の記載は，ただ一葉の地質断面図（図 2）がある にすぎない.

トリニル地域の地質調查は，1907〜1908 年のドイッ の SELENKA 夫人の発掘調査に参加した地質学者の CARTHAUS (1911) と Dozy (1911)，オランダの Es (1931)

* 大阪市立大学理学部地学教室, Department of Geosciences, Faculty of Science, Osaka City University.

** 東京大学理学部人類学教室, Department of Anthropology, Faculty of Science, University of Tokyo. 


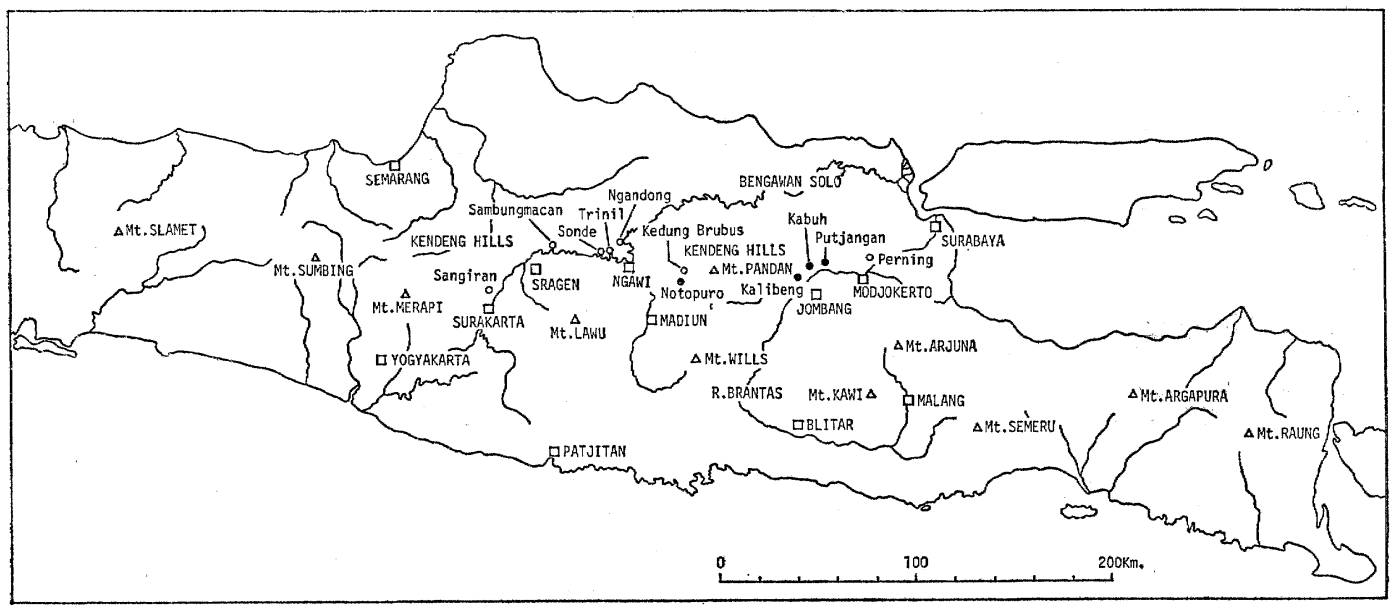

困 1 中部・東部ジャワの人類化石産地と鮮新・更新統の模式地

$\bigcirc$ : 人類化石産地,

：地層模式地

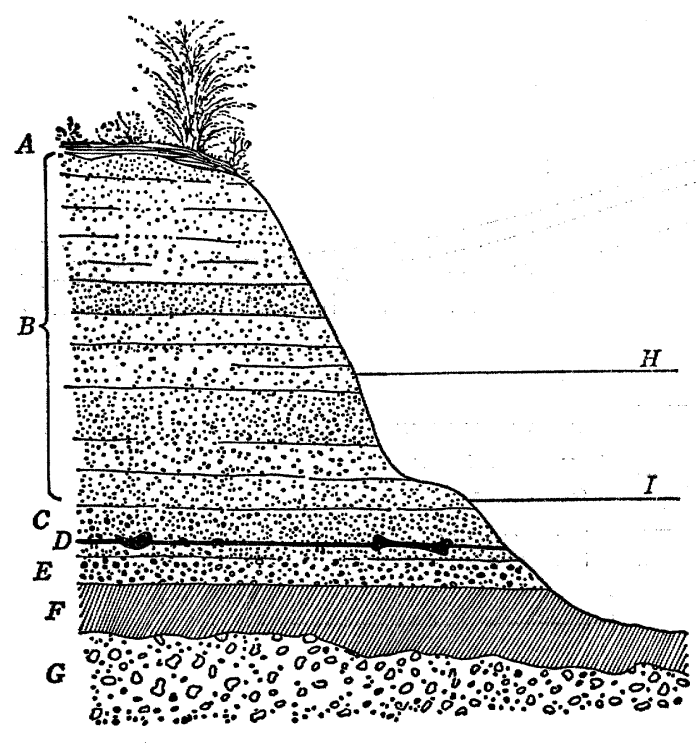

図·2 トリニルの Pithecanthropus erectus 産出地 点の地質断面図 (Dubors, 1896),

一 Konigswald (1940) より一

$\mathrm{A}:$ 土裹, B : 軟砂岩, $\mathrm{C}:$ Lapilli (火山 礫）層， D : Pithecanthropus の発見された 層準, $\mathrm{E}$ : 硆岩, $\mathrm{F}$ : 粘土層, $\mathrm{G}$ : 角頼岩 (海成), $\mathrm{H}$ : 雨期のソロ川の水位, $\mathrm{I}$ : 乾 期のソロ川の水位. (KonigswalD は， G 層は海成ではなく，陸成であると記してい る.トリニルのソロ川川岸の崖の比高は10 数 $\mathrm{m}$ である.)
やDUYFJES (1936) によっておこなわれた. CARThaus と Dozy は, Dubors の G 層が Lahar (泥流) 礫岩 層, 磞質凝灰岩層であることを指摘している. 図 3 に DUYFJESによるトリニル地域の南北方向の地質断面図を 示した、下部カリブング層は Globigerina を含生泥灰岩 や砂岩から，上部カりブング層はおもに砂質泥灰岩をは さむ石灰岩から，プチャンガン層は Lahar (泥流) 角碩 岩から, カブー層とノトプロ層は砂岩, 砂岩, 凝存岩, 粘土から構成されている，これらの各地層は南にゆるく 傾斜している. 図 3 の地質断面図には垂直スケールは示 されていないが，プチャンガン層の層厚は約 $100 \mathrm{~m}$ と記 されているので, 各層の層厚の概略を知ることができる. Pithecanthropus 1 化石の産出層準はカブー層の基底とさ れている.

カリブング層, プチャンガン層, カブー層, ノトプロ 層は，いずれも DUYFJES (1936) の命名による地層であ って, ケンデン丘陵地域に分布している. それらの模式 地は図 1 に示したようにトリニルの東方 $20 １ 00 \mathrm{~km}$ に ある.カリブング層は Lepidocyclina 層（中新統）にひ きつづいて堆積した鮮新統，プチャンガン層は一般には 火山性堆積物のほかに海成の粘土質堆積物をともない, Stegodon trigonocephalus cf. praecursor, Hippopotamus antiquus などの Djetis 動物群を産出し, 前期更新統と されている.カブー層は,おもに陸水成堆積物からなり， Stegodon trigonocephalus, Elephas cf. namadicus, Hippopotamus namadicus などの Trinil 動物群をとない中期 更新統，ノトプロ層は特徵的な化石を含有しないが，段 


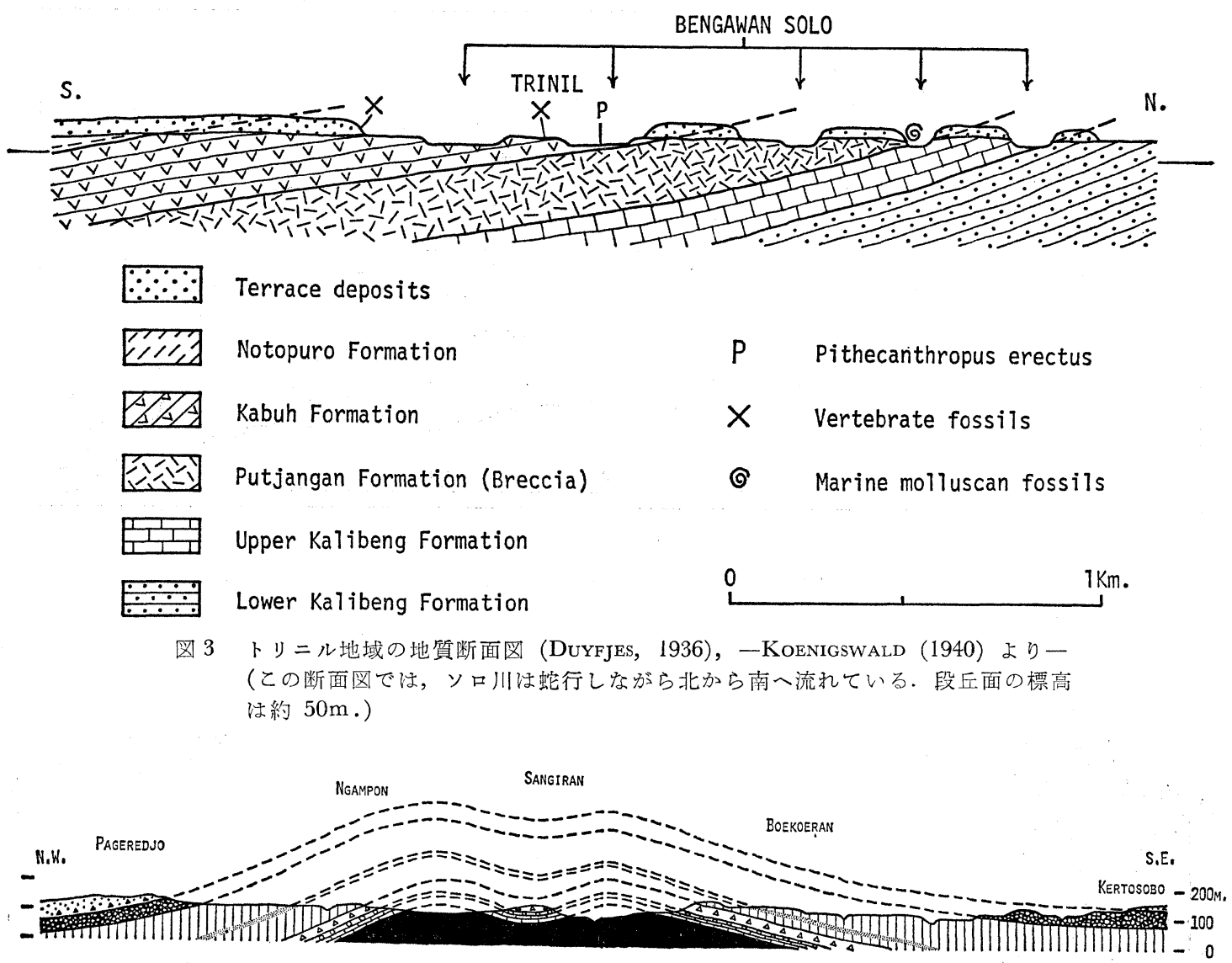

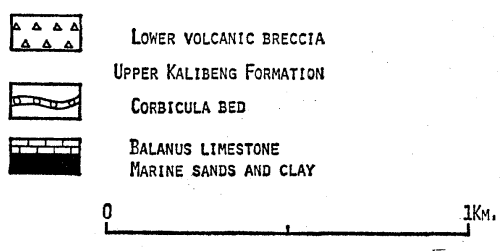

IKM.

図 4 サンギラン地域の地質断面図（KoENIGSWALD，1940).

丘層より古い地層で，やはり中期更新統に属すると考え られている (MARKs, 1961).

\section{サンギラン}

サンギランはスラカルタの北方約 $12 \mathrm{~km}$ にあって，そ の周辺には標高約 $150 \mathrm{~m}$ の丘陵がひろがっている.サン ギラン地域は，ドーム構造の発達と，その構造を切るチ ニモロ川（ソロ川の支流）の開析のために，よい露出に めぐまれている.

サンギラン地域の地質調査は，Es (1931) KoEnIGs-
WALD (1940) やSARTONo (1961，1970) などによって おこなわれた。これらの調查のうち, Es の調査がもっ とも詳細で, その後の調査の基本となっている.

図4（KoENIGSWALD，1940) に示したように, サンギ ラン・ドームを構成している地層の層序は, トリニル地 域の層序と同様に，下位より，カリブング層，プチャン ガン層, カブー層, ノトプロ層である.この地域のカリ ブング層は上部カリブング層と考えられていて，下位よ り，層厚不詳の青灰色の海成粘土層, Turritella 含含 粘土質砂層 (層厚 $30 \mathrm{~m}$ 以下, Es の Turritella 層), 


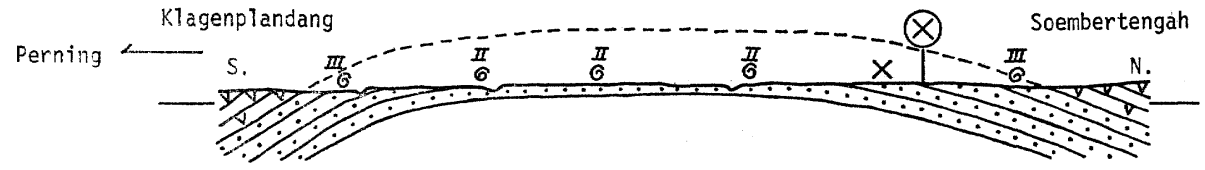

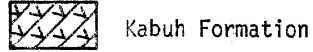

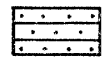

$\overline{6}$ III Horizon of marine mollusca

図 5 モジョケルトの北東方地域の地質断面図

\section{Q Homo modjokertensis}

\section{Vertebrate fossils}

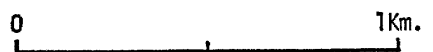

(Duyfjes, 1936)，一Koenigswald (1940) より一

Balanus石灰岩層（層厚 $2 \mathrm{~m}$ 以下), Corbicula 層（最大 層厚 $10 \mathrm{~m}$ 以上）よりなっている. プチャンガン層はカ リブング層を discordantにお抢う下部火山角礫岩層(層 厚約 $30 \mathrm{~m}$ ） とその上位の 淡水成の黑色粘土層（層厚約 $200 \mathrm{~m}$ ) より構成され，黑色粘土層の下底より約 35〜40 $\mathrm{m}$ 上位に珪藻土をともなう海成層をはさむとされてい る. しかし, 最近の研究 (KADAR, 1966) によれば, こ の黑色粘土層はほぼ全層準にわたって有孔虫化石を産出 することが知られている. カブー層 (下部䃯岩・凝灰岩 層）は石灰質の境界層（層厚 $1 \mathrm{~m}$ 内外）にはじまり，陸水 成の砂・磇・粘土層と凝兏岩層によって構成され，その 層厚は $50 \mathrm{~m}$ 以下である. ノトプロ層（上部火山角砅岩 層と上部碩岩・凝灰岩層）はカブー層を discordant に

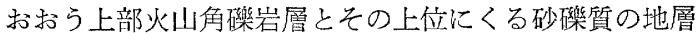
や凝灰岩層から構成され，その層厚注数 $10 \mathrm{~m}$ である.

サンギラン地域のプチャンガン層からカブー層にかけ ての地層からは, Pithecanthropus の頭蓋骨 $(P . \mathbb{I} \sim \mathbb{N}$, $P . \mathrm{V} \sim \mathrm{Vill})$ ，同下顎骨 $(P . \mathrm{b}, P . \mathrm{c})$, Meganthropus palaeojavanicus の下顎骨 $(M . \mathrm{a}, M . \mathrm{b})$ などの多くの人類 化石が発見されている(KoENIGSWALD，1940；SARTONo， $1961 \cdot 1975)$.

\section{モジョケルト}

モジョケルトに近いプルニングの北方には, 標高 50 〜 $100 \mathrm{~m}$ の丘陵地がある.この地域の地質調查は DUYFJES （1936）によっておこなわれた，地質断面図（図 5 ）に 示したように，東西方向の背斜構造が発達していて，そ れはクドングワル背斜とよばれている．背斜の軸部をし めるプチャンガン層の層序は，下位より，a）凝灰質砂 岩層 (層厚 $25 \mathrm{~m}$ 内外), b ) 砂户海生貝化石 (層準 II) をふくも泥灰・粘土質の凝灰質砂岩層（層厚 $15 \mathrm{~m}$ )， c ） ところどころに粘土をともなう細粒の凝死質砂岩層（層
厚 $10 \mathrm{~m}$ ), d ) 䃯をともなう粗粒の砂岩層 (層厚 $100 \mathrm{~m}$ ), e ) 緑色の粘土層 (層厚 $5 \mathrm{~m}$ )， f) 海生貝化石 (層準 III）をふくむ泥灰・凝灰質砂岩層（層厚 $10 \mathrm{~m}$ )， g ）粗・ 細粒砂岩層 (層厚 $35 \mathrm{~m}$ ) である. Homo modjokertensis （子供の頭蓋骨化石）は 1936 年にd 層から発掘された。

カブー層は背斜の両翼に分布していて, 砂岩層と凝灰 岩層で構成されている. その層厚は約 $50 \mathrm{~m}$ である.

\section{化石人 類}

ジャワの化石人類は，その産出層準によって新旧二つ の時代にわけられる.ただし戦後に発見された $P . \mathbb{I} 〜$ 调などについては，ここではふれないことをおことわり しておく. 新しいほう (P. erectus) には $P$. a (ケドウ ン・ブルブスの下顎骨)，P. I 〜 III，古いほうには Homo modjokertensis, P. b, P. N, P. dubius, Meganthropus

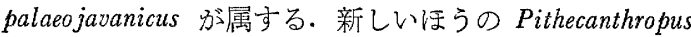
が小型なのに対して，古いほうは大きくて原始的な特徵 をもっている．最近では，プルニング北方産の Homo modjokertensis, P. b，P. N は，一括して Pithecanthropus modjokertensis とされてきている. $P . \mathbb{N}$ は WEIDENREICH (1945) が P. robustus と名づけたものである.

Meganthropus については, 当然 Australopithecus との 関係が間題となる. ToBIAs \& KoEnigswaLD (1964) はアフリカの人類化石と Meganthropus, P. b , P. IV, P. dubius などの比較をこころみた. その結果，Meganthropus は Australopithecus に似た特徵をむつが，より進 えだ段階のもので，それがよく似ているのは Homo habilis, P. N と P. b はオルドヴォイ II 層下半の Homo habilis およびスウォルトクランズの Telanthropus に似 ているとされた.このようにして，アジアにもアフリカ と同様に Australopithecus と Homo habilis 段階のもの が，共存した可能性が示唆されるのである. 


\section{絶対 年 代}

ジャワは火山島であるから，ジャワの化石人類含有層 にはしばしば火山性堆積層が挾在されていて，絶対年代 測定のための有効な試料を採取することができる。まだ その数は少ないが，すでに，いくつかの測定結果が報告 されている.

プルニング北方の Homo modjokertensis 化石を含有す るプチャンガン層の軽石凝灰岩の $\mathrm{K}-\mathrm{Ar}$ 年代は $190 \pm 40$ 万年 (JACOB and Curtis, 1971) である. サンギラン のカブー層中のテクタイトの $\mathrm{K}-\mathrm{Ar}$ 年代は 70万年 $(\mathrm{KOE}-$ NIGSWALD，1968)，中部ジャワの Trinil 動物群を含有す る地層をおおう立武岩の $\mathrm{K}-\mathrm{Ar}$ 年代注約 50 万年(EVER. NDEN and GURTIS，1965)である. 数少ない測定值から， ただちに結論することはできないが，これらの絶対年代 は，いままでの層序学的研究と矛盾していない.

\section{あとがき}

ジャの人類化石含有層について，その層序，化石人 類，絶対年代をごく簡単に説明した. はじめにふれたジ ヤワの人類化石含有層のインドネシア・日本の共同研究 はバンドン地質調查所と東京大学をそれぞれの協力機関 として，1976 年より発足した. 1976 年は 8 〜月の 2 ケ月間，インドネシア側は隊長・D. KADAR 氏ほか 10 名, 日本側は隊長・渡辺直経注か柴崎達雄, 古山勝彦, 林 隆夫, 市原 実が, サンギランをはじめとし, 主要 な人類化石産地周辺の層序学的研究に従事した. この共 同研究は今後も人類学, 古生物学, 絶対年代, 古地磁気 などの研究分野を加えて継続され，研究結果はバンドン 地質調查所より出版されることになっている.

\section{引用 交 献}

Carthaus, E. (1911) Zur Geologie von Java, insbesondere des Ausgrabungsgebietes. In SelenkA, L. und Blanckenhorn, M. (Hg.) Die PithecanthropusSchichten auf Java-Geologische und Palaeontologische Ergebnisse der Trinil-Expedition (1907 1908)-. XLII +268 pp., Wilhelm Engelmann, Leipzig : pp. $1-33$.

Dozy, G. M. (1911) Bemerkungen zur Stratigraphie der Sedimente in der Triniler Gegend. ibid. : pp. $34-36$.
Dubors, I. (1896) Pithecanthropus erectus, eine Stammform des Menshen. Anatomischer Anzeiger, 12, $1-22$.

Durfues, J. (1936) Zur Geologie und Stratigraphie des Kendenggebietes zwischen Trinil und Soerabaya (Java). De Ingenieur in Ned. Indië, Sect. IV, 3, 136 -149 .

Es, L.J. C. van (1931) The Age of Pithecanthropus. 142 pp., Martinus Nijhoff, the Hague.

Evernden, J. P. and Curtis, G. H. (1965) The potassium-argon dating of Late Cenozoic rocks in East Africa and Italy. Current Anthropology, 6, $343-385$.

Jacoв, T. and Curtis, G. H. (1971) Preliminary potassium-argon dating of early man in Java. Contributions of the University of California Archaeological Research Facility, 12, 50.

KadAR, D. (1966) Fauna foraminifera ketjil dikubah, Djawa Tengah. Master thesis, Geological Department, Institute Technology Bandung.

Koenigswald, G. H. R. von (1940) Neue Pithecanthropus-Funde, 1936-1938. Wentensch. Meded. Dienst Mijnb. Ned. Indie, 28, 1-125.

Koenigswald, G. H. R. von (1968) Das absolute Alter des Pithecanthropus erectus DuBois. In Kurth, G.(ed.) Evolution und Hominisation. Gustav Fischer, Stuttgart.

Marks, P.(1961) Stratigraphic Lexicon of Indonesia. Publikasi Keilmuan, Direktorat Geologi Bandung, Seri Geologi, 31, 1-233.

Sartono, S. (1961) Notes on a new find of a Pithecanthropus mandible. Publikasi Teknik, Direktorat Geologi Bandung, Seri Paleontologi, 2, 1-51.

Sartono, S. (1970) On the stratigraphic position of Pithecanthropus mandible-C. Proceedings Institut Teknologi Bandung, 4, (4), 91-102.

SARtono,S . (1975) Implications arising from Pithecanthropus VIII. In TutTle, R.H.(ed.) Paleoanthropology, Morphology and Paleoecology. 453 p., Mouton, Paris: pp. $327-360$.

Tobias, P.V. and Koenigswald, G.H.R. von (1964) A comparison between the Olduvai hominines and those of Java and some implications for hominid phylogeny. Nature, 204, 515-518.

渡辺直経 (1976) ジャワのアウストラロピテクス，自然 31, (2), 54-63.

Weidenreich, F. (1945) Giant early man from Java and South China. Anthropological Papers, American Museum Natural History, 40, (1), 1-134. 